\title{
THE COMPARATIVE STUDY ON THE COMPOSITION OF ACYLGLYCEROLS AND FATTY ACIDS IN CELERY, PARSNIP AND BLACK RADISH ROOTS
}

\author{
Jelena S. Mitrović ${ }^{*}$, Nada Č. Nikolić1, Ivana T. Karabegović1 ${ }^{1}$ Zoran B. Todorović1, \\ Miodrag M. Lazić ${ }^{1}$, Gordana S. Stojanović \\ (ORIGINAL SCIENTIFIC PAPER) \\ UDC 582.794.1:577.115:661.188.8 \\ 1University of Niš, Faculty of Technology, Department of Food and Biotechnology, Leskovac, Serbia \\ 2University of Niš, Faculty of Science and Mathematics, Department of Chemistry, Niš, Serbia
}

Celery, parsnip and black radish are edible root vegetables suitable for different salads. Fatty acids and acylglycerols are usually minor components of most foods, but in the human diet some of them, such as omega-3 and omega- 6 fatty acids, are important for the growth, reproduction, good health, and prevention of cardiovascular disease. Therefore, identifying and comparing of the lipid composition of celery, parsnip and black radish root may have importance in choosing the root and predicting a nutritional and health value of food products. In this paper, the lipid content and fatty acids and acylglycerols composition in celery, parsnips and black radish roots were investigated and compared. The results indicate that the parsnip roots had the slightly higher lipid content $\left(0.077 \mathrm{~g} \mathrm{~kg}^{-1}\right)$ than celery and black radish roots ( 0.036 and $0.037 \mathrm{~g} \mathrm{~kg}^{-1}$, respectively). The lipids in celery and black radish roots had the highest content of free fatty acids $\left(5.46\right.$ and $\left.4.25 \mathrm{~g} \mathrm{~kg}^{-1}\right)$, while the parsnip roots had the highest content of triacylglycerols $\left(4.54 \mathrm{~g} \mathrm{~kg}^{-1}\right)$. In the case of fatty acids, in the lipids found in celery and parsnip roots, linoleic acid was the most abundant (31.03 and $59.22 \%$, respectively), and in the lipids of black radish roots, linolenic acid $(55.71 \%)$ had the greatest value.
Keywords: acylglycerols, celery, fatty acids, lipid, parsnip, radish

\section{Introduction}

Celery, parsnip and black radish are edible root vegetables, cultivated and used worldwide for their nutritional and medicinal values. Vegetables are often identified as the most important part of a diet, assuring life-long health and preventing the age-related disease [1,2]. Celery (Apium graveolens Linn.) belongs to the Umbelliferae family. It is valued as a spice due to its warm and pleasing flavor. Celery seeds contain a particular compound, 3- $n$ butylphthalide, that has been shown to lower the blood pressure [3], and is used in weight-loss diets as it provides low-calorie dietary fibers [4]. Parsnip (Pastinaca sativa L.) has a sweet and nutty flavor with a parsnip-like aroma. It is a root vegetable related to the carrot, except for its light yellow color and, unlike the carrot it does not contain beta-carotene. Instead, it has a stronger flavor and is richer in vitamins and minerals than most carrots. Parsnip is particularly rich in vitamin $\mathrm{C}$ and potassium and is also a good source of dietary fibers [5]. Consumption of parsnip has health benefits, as the high content of fiber prevents constipation and reduces blood cholesterol levels [6]. The black radish (Raphanus sativus L. var. niger) is a plant belonging to the Cruciferae family. In folk medicine, the black radish root has been used as a natural drug against flatulence, the formation of gallstones and onset of indigestion [7-9] and for the stimulation of bile function [10,11].
Significant antiurolithiatic effects of black radish were also reported [12]. Since phenolic compounds take part in anti-mutagenic, anti-carcinogenic [13-15] and antioxidant activities [16], have anti-inflammatory [17,18] and anti-fungal properties [19] and have the ability to reduce cardiovascular and carcinogenic risk [20], the phenolic compounds in celery, parsnip and black radish are often investigated [21-24].

As lipids components, fatty acids are usually minor components of most foods but are major components of some specialty foods and/or supplements. Accordingly, FAO/WHO recommendations are carefully interpreted with respect to some fatty acids. Based on chemical classifications i.e. the number of double bonds, fatty acids is broadly grouped into saturated fatty acids, monounsaturated fatty acids and polyunsaturated fatty acids, as major groups. These groups of fatty acids are mainly associated with different health effects but also within each broad classification, the Expert Consultation recognized individual fatty acids as unique biological properties with health effects. In human diet, fatty acid, myristic acid (14:0), palmitic acid (16:0) (PA), and stearic acid (18:0) (SA) are indicated as major saturated fatty acids, oleic acid (18:1 $\mathrm{n}-9)$ as the main monounsaturated fatty acid although in some populations erucic acid takes on this role. The two

\footnotetext{
*Author address: Jelena Mitrović, University of Niš, Faculty of Technology,

Department of Food and Biotechnology, Bulevar oslobodjenja, 124, 16000 Leskovac, Serbia

E-mail: mitrovic_jelena91@hotmail.com

The manuscript received: April, 03, 2018.

Paper accepted: April, 30, 2018.
} 
principal families of polyunsaturated fatty acids that occur in nature are omega- $6(n-6)$ and omega- $3(n-3)$ fatty acids. They are biosynthetically derived from linoleic acid (18:2 n-6) (LNA) and linolenic acid (18:3 n-3) (LNNA), respectively, and can be synthesized in plants but not in animal tissue, and must be obtained from food [25]. Omega-3 and omega- 6 are important for growth, reproduction and good health, and for the prevention of cardiovascular disease $[26,27]$, and accordingly must be included in human diet, ultimately from plants [28-30]. Therefore, identifying the lipid composition of edible plants may have great importance.

To best of our knowledge, there are only few data on the lipid content and composition in celery, parsnip, and black radish plant, especially roots. There are data that celery seeds contain $15 \%$ fatty oil with petroselinic $(64.3 \%)$, oleic $(8.1 \%)$, linoleic $(18 \%)$, linolenic $(0.6 \%)$, and palmitic acids [31]. Considering these facts, the aim of this research was to investigate at the same time and under the same experimental conditions and compare the lipid content (LC) and composition, with an emphasis on fatty acids and acylglycerols in celery (CR), parsnip (PR) and black radish roots (BRR). The identifying and comparing the lipid composition in these plants may have importance in choosing the root among celery, parsnip and black radish roots and in predicting the nutritional and health value of salads and other products for food industry.

\section{Materials and methods}

\section{Plant material}

Celery (Apium graveolens L.) roots cv Golden Boy, black radish (Raphanus sativus L.) roots cv Niger and parsnip (Pastinaca sativa L.) roots cv Pannonian smooth were used. All roots were grown in Serbia and bought in a local store. The roots were various masses (from approximately 30 to $350 \mathrm{~g}$ ), and the average mass of celery, parsnip and black radish roots was 200, 180 and $230 \mathrm{~g}$, respectively. In order to obtain the samples for analyses, the mixed roots (about $1 \mathrm{~kg}$ ) were cut in a cube shape $(1.5 \times 1.5 \times 1.5 \mathrm{~cm})$, dried at $35^{\circ} \mathrm{C}$ for $6 \mathrm{~h}$, left at the room temperature for $1 \mathrm{~h}$ and milled to an average particle size of $0.5 \mathrm{~mm}$.

\section{Moisture content}

In order to compare the lipid contents, the moisture content of the samples was determined and the lipid content was expressed per dry matter. The sample moisture content was determined by using the analyzer (Scaltec SMO 01, Scaltec Instruments, Göttingen, Germany). The fresh plant material $(10 \mathrm{~g})$ was dried at $110{ }^{\circ} \mathrm{C}$ to a constant weight, and the moisture content was read out on the analyzer display. Determinations were repeated in triplicate and the values represented as the means and standard deviation.

Lipid content

The lipid content in the samples was determined by the trichloroethylene duplicate extraction with reflux (1:20 w/v, at boiling temperature during 60 minutes). The extracts were combined and $3 \mathrm{~mL}$ of the obtained extract was dried at $110{ }^{\circ} \mathrm{C}$ to a constant weight. Then, the lipid residue content was read out on the analyzer display (Scaltec SMO 01, Scaltec instruments, Germany).

Based on the mass of the lipid residue, the volume of the combined extracts and the mass of the samples used for the lipid extraction, the lipid content was calculated and expressed as $\mathrm{g} \mathrm{kg}^{-1}$ of the dry matter. For determination of fatty acids and the acylglycerols composition, the rest of combined trichloroethylene extracts was evaporated under vacuum and the lipid residue was obtained. Determinations were repeated in triplicate and the values represented as the means and standard deviation.

HPLC analysis

For HPLC analysis of isolated lipids, HPLC method [32] and the Agilent 1100 High Performance Liquid Chromatograph, a Zorbax Eclipse XDB-C18 column: $4.4 \mathrm{~m} \times$ $150 \mathrm{~mm} \times 5 \mu \mathrm{m}$ (Agilent Technologies, Wilmington, USA), and an UV/Vis detector were used. The lipid residue was dissolved into the mixture of 2-propanol $/ n$-hexane, 5:4 v/v and filtered through $0.45 \mu \mathrm{m}$ Millipore filters. The flow rate of the binary solvent mixture (methanol, solvent $A$, and 2-propanol/n-hexane, 5:4 by volume, solvent $B$ ) was $1 \mathrm{~mL}$ min $^{-1}$ with a linear gradient (from $100 \%$ A to $40 \% A+60 \%$ $B$ in $15 \mathrm{~min}$ ). The column temperature was held constant at $40{ }^{\circ} \mathrm{C}$. The components were detected at $205 \mathrm{~nm}$.

Monoacylglycerols (MAG), diacylglycerols (DAG) and triacylglycerols (TAG) were identified by comparing the retention times of the lipids components with those of standards. Their contents were determined by measuring the peak area from 3.445 to 4.580 min for MAG, the peak area from 5.276 to $8.677 \mathrm{~min}$ for DAG and the peak area from 10.907 to 15.815 min for TAG. Determinations were repeated in triplicate and the results represented as the means and standard deviation, and expressed as $g$ of the component per $\mathrm{kg}$ of the lipid.

\section{GC analysis}

For GC analysis, fatty acids methyl esters were prepared. The lipid residue was alkaline hydrolyzed and methylated by methanol and boron trifluoride (BF3) as catalysts. The final fatty acids methyl esters concentration was about $8 \mathrm{mg} \mathrm{mL}^{-1}$ in heptane. For obtaining a methyl esters GC spectra, the HP 5890 SERIES II GAS-CHROMATOGRAPH, HP with FID detector and 3396 A HP integrator was used. The column was ULTRA 2 (25 $\mathrm{m} \times 0.32$ $\mathrm{mm} \times 0.52 \mu \mathrm{m})$ (Agilent Technologies, Wilmington, USA), the injector temperature of $320^{\circ} \mathrm{C}$, and the injector volume of $0.4 \mu \mathrm{L}$. The carrier gas was $\mathrm{He}$ at a constant flow rate of $1 \mathrm{~mL} \mathrm{~min}{ }^{-1}$. The flame ionization detector was at $350{ }^{\circ} \mathrm{C}$ and the split ratio was $1: 20$. Initially, the oven temperature was $120^{\circ} \mathrm{C}$ and it was maintained at $120^{\circ} \mathrm{C}$ for 1 min, then increased by $15^{\circ} \mathrm{C} \mathrm{min}$ mil $^{-1}$ until $200^{\circ} \mathrm{C}$, increased by $3{ }^{\circ} \mathrm{C} \mathrm{min}$ mi $^{-1}$ until $240{ }^{\circ} \mathrm{C}$, increased by $8{ }^{\circ} \mathrm{C} \mathrm{min}{ }^{-1}$ until $300{ }^{\circ} \mathrm{C}$ and maintained at $300{ }^{\circ} \mathrm{C}$ for 15 min. Fatty acids 
were identified by comparison of retention times of the lipids components with those of standards. Determinations were repeated in triplicate and the results are expressed as the percentage of the total area of identified fatty acids and non-fatty acids components.

\section{Statistical analysis}

Software Statistica version 5.0 (StatSoft, Tulsa, Oklahoma, USA) was used to perform the statistical analysis: the mean, standard deviation, the correlation coefficients and the cluster analysis. The mean and standard deviations were obtained by using Descriptive Statistics, marking the Median \& Quartiles and Confirm Limits for Means. In order to classify the samples into groups, the cluster analysis and the Euclidean method with the complete linkage was used.

\section{Results and discussion}

\section{Lipid content}

The moisture content in the studied samples of celery, parsnip and black radish roots was $0.877 \pm 0.12$, $1.173 \pm 0.15$ and $1.216 \pm 0.14 \%$, respectively. The lipid content in celery roots was $0.032 \pm 0.01 \mathrm{~g} \mathrm{~kg}^{-1}$, in parsnip roots it was $0.068 \pm 0.02 \mathrm{~g} \mathrm{~kg}^{-1}$ and $0.033 \pm 0.01 \mathrm{~g} \mathrm{~kg}^{-1}$ in black radish. Based on the moisture content in the studied samples, the lipid content calculated per dry matter was 0.036 , 0.077 and $0.037 \mathrm{~g} \mathrm{~kg}^{-1}$ in celery, parsnip and black radish roots, respectively. These results show the parsnip roots had the slightly higher lipid content than other roots.

Acylglycerols composition

The lipid profile obtained by the HPLC analysis is pre- sented in Table 1 and chromatograms in Figure 1. The lipids in celery roots and black radish roots had the highest content of free fatty acids (FFA) $\left(5.46\right.$ and $\left.4.25 \mathrm{~g} \mathrm{~kg}^{-1}\right)$, while the parsnip roots had the highest content of TAG $\left(4.54 \mathrm{~g} \mathrm{~kg}^{-1}\right)$, and the content of FFA was also high $(4.09 \mathrm{~g}$ $\left.\mathrm{kg}^{-1}\right)$. Based on the content of DAG, the lipids in the parsnip vary significantly from the lipids in celery and black radish roots, as the content of lipids in celery roots was 1.39 and $1.73 \mathrm{~g} \mathrm{~kg}^{-1}$, and in parsnip roots the content of DAG was only $0.04 \mathrm{~g} \mathrm{~kg}^{-1}$.

Table 1. Free fatty acids (FFA), methyl esters (ME), monoacylglycerols (MAG), diacylglycerols (DAG) and triacylglycerols (TAG) content in celery, parsnip and black radish roots obtained by HPLC analysis

\begin{tabular}{lccc}
\hline $\begin{array}{c}\text { Component/Content } \\
\text { (g kg-1 lipid) }\end{array}$ & $\begin{array}{c}\text { Celery } \\
\text { roots }\end{array}$ & $\begin{array}{c}\text { Parsnip } \\
\text { roots }\end{array}$ & $\begin{array}{c}\text { Black radish } \\
\text { roots }\end{array}$ \\
\hline FFA & $5.46 \pm 0.33$ & $4.09 \pm 0.35$ & $4.25 \pm 0.37$ \\
ME & $0.63 \pm 0.04$ & $0.41 \pm 0.06$ & $0.16 \pm 0.02$ \\
MAG & $0.05 \pm 0.01$ & $0.02 \pm 0.01$ & $0.01 \pm 0.01$ \\
DAG & $1.39 \pm 0.07$ & $0.04 \pm 0.01$ & $1.73 \pm 0.13$ \\
TAG & $2.47 \pm 0.14$ & $4.54 \pm 0.42$ & $3.85 \pm 0.41$ \\
\hline
\end{tabular}

${ }^{*}$ values are the means and standard deviation $(n=3)$

Fatty acids composition

The results of the GC analysis of celery, parsnip and black radish root lipids, with an emphasis on total monounsaturated fatty acids (TMUFA), total polyunsaturated fatty acids (TPUFA), total unsaturated fatty acids (TUFA), total saturated fatty acids (TSFA) and the ratio of total unsaturated fatty acids to total saturated fatty acids (TUFA/TSFA) are shown in Table 2. Peaks with an area less than $0.15 \%$ of the total area are disregarded.

Table 2. Components (\% of total components) in lipids of celery, parsnip and black radish roots detected by GC analysis

\begin{tabular}{|c|c|c|c|}
\hline $\begin{array}{c}\text { Component } \\
(\%)\end{array}$ & Celery roots & Parsnip roots & Black radish roots \\
\hline $\begin{array}{l}\text { Phtalic acid } \\
\text { Valeric acid } \\
\text { Myristicin } \\
\text { 3-n-Butylphthalide } \\
\text { Perhydroazulene } \\
\text { Behenic acid } \\
\text { Silicic acid } \\
\text { Myristic acid (14:0) } \\
\text { Pentadecanoic acid }(15: 0) \\
\text { Palmitic acid }(16: 0)\end{array}$ & $\begin{array}{l}0.73 \pm 0.09 \\
0.35 \pm 0.05 \\
0.90 \pm 0.11 \\
3.62 \pm 1.23 \\
1.22 \pm 0.41 \\
0.16 \pm 0.03 \\
0.45 \pm 0.12 \\
0.16 \pm 0.08 \\
0.40 \pm 0.11 \\
9.60 \pm 0.86\end{array}$ & $\begin{array}{c}0.16 \pm 0.07 \\
\text { nd } \\
8.92 \pm 1.2 \\
\text { nd } \\
\text { nd } \\
\text { nd } \\
\text { nd } \\
\text { nd } \\
\text { nd } \\
14.69 \pm 2.58\end{array}$ & $\begin{array}{l}\text { nd } \\
\text { nd } \\
\text { nd } \\
\text { nd } \\
\text { nd } \\
\text { nd } \\
\text { nd } \\
\text { nd } \\
\text { nd } \\
23.63 \pm 1.98\end{array}$ \\
\hline $\begin{array}{l}\text { Margaric acid (17:0) } \\
\text { Palmitoleic acid }(16: 1 \mathrm{n}-7) \\
\text { Ammoidin } \\
\text { Bergapten }\end{array}$ & $\begin{array}{c}0.18 \pm 0.03 \\
\text { nd } \\
0.62 \pm 0.5 \\
1.39 \pm 0.75\end{array}$ & $\begin{array}{l}0.13 \pm 0.05 \\
0.62 \pm 0.07 \\
\text { nd } \\
\text { nd }\end{array}$ & $\begin{array}{l}\text { nd } \\
\text { nd } \\
\text { nd } \\
\text { nd }\end{array}$ \\
\hline Linoleic acid (18:2 n-6) & $31.03 \pm 2.92$ & $59.22 \pm 6.31$ & $9.08 \pm 1.17$ \\
\hline Linolenic acid (18:3 n-6) & $4.57 \pm 0.58$ & $10.97 \pm 2.24$ & $55.71 \pm 6.35$ \\
\hline Oleic acid $(18: 1 n-9)$ & nd & $4.15 \pm 0.75$ & $8.34 \pm 1.12$ \\
\hline Stearic acid $(18: 0)$ & $0.16 \pm 0.08$ & $0.37 \pm 0.06$ & $0.94 \pm 0.11$ \\
\hline 1,2 Benzenedicarboxylic acid & $7.06 \pm 0.29$ & $0.16 \pm 0.05$ & $1.10 \pm 0.09$ \\
\hline Sitosterol & $2.45 \pm 0.02$ & nd & nd \\
\hline TSFA & 10.34 & 15.19 & 24.57 \\
\hline TMUFA & - & 4.77 & 8.34 \\
\hline TPUFA & 35.60 & 70.19 & 64.79 \\
\hline TUFA & 35.60 & 74.96 & 73.13 \\
\hline TUFA/TSFA & 3.44 & 4.93 & 2.98 \\
\hline
\end{tabular}



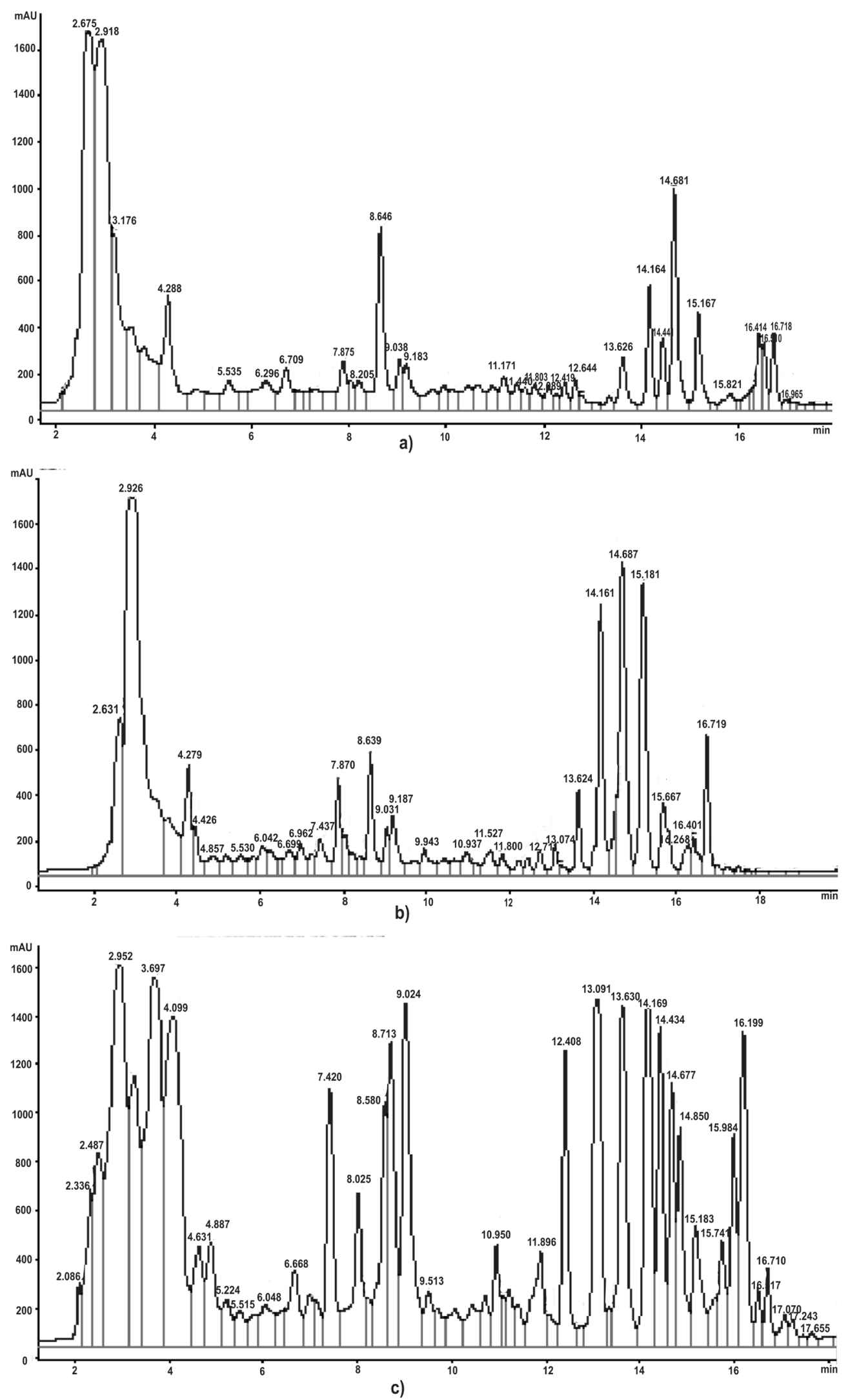

Figure 1. HPLC chromatograms of lipids from celery roots (a), parsnip roots (b) and black radish roots (c) 
The GC analysis showed that the lipids from celery roots contained 18 identified components, from parsnip 10 , and from black radish roots 6 components. Among non-fatty acid components in celery roots, the lipids included phtalic acid, valeric acid, myristicin, 3- $n$-butylphthalide, perhydroazulene, behenic acid, silicic acid, ammoidin, bergapten, 1,2 benzenedicarboxylic acid and sitosterol. In these lipids, the monounsaturated oleic fatty acid was a non-identified component. In the parsnip root lipids, among the non-fatty acid components which were presented in celery root lipids, only phtalic acid, myristicin and 1,2 benzenedicarboxylic acid were identified, while the oleic fatty acid was present as well. Black radish root lipids had the smallest number of identified components, and there were no components which were identified in black radish root lipids and in celery and parsnip root lipids.

1,2 benzenedicarboxylic acid was the only non-fatty acid component. It is interesting that the most abundant fatty acid was linoleic acid (31.03 and $59.22 \%$ in celery and parsnip roots, respectively) and in black radish roots, the lipids consisted of linolenic acid $(55.71 \%)$. Regardless of these results, and considering the highest lipid content was found in celery roots, it is to be expected that the highest amount of linolenic acid was found in celery roots. In our available literature, there are no data on the composition of fatty acids in roots of the investigated, as well as related plant species. However, there are data about the fatty acid composition of radish seeds lipids and vacuolar lipids isolated from root tissues of parsnip. According to this research, the most abundant fatty acid was linolenic acid (52-55\% in radish seeds) [33], and linoleic acid (53.5\% in vacuolar lipids of parsnip) [34]. These results are in accordance with our research with regard to the most abundant fatty acids.

The content of total saturated fatty acids in celery, parsnip and black radish root lipids was 10.34, 15.19 and $24.57 \%$, respectively, and the content of total polyunsaturated fatty acids was $35.60,74.96$ and $73.13 \%$, respectively. It is known that polyunsaturated fatty acids maintain the cell membrane fluidity and the membrane protein function. Hence, they regulate such processes as gene expression and cell signaling [25], and the highest proportion of polyunsaturated fatty acids in our studied samples was found in parsnip root lipids. Due to these results, the ratio of the total unsaturated fatty acid content to the total saturated fatty acid was the highest in parsnip root lipids (4.93) and the lowest in black radish root lipids (2.98), while in the celery root lipids it was 3.44 .

Correlation matrix and dendrogram

The correlation coefficients between lipids parameters (LC, FFA, MAG, DAG and TAG, PAM, LNA, LNNA and STA, TSFA and TUFA) of celery, parsnip and black radish root lipids are presented in Table 3 .
Table 3. Correlation matrix between lipid components of celery, parsnip and black radish root (correlations are significant at $\mathrm{p} \leq 0.5)$

\begin{tabular}{lrlllllllll}
\hline & LC & FFA & MAG & DAG & TAG & PAM & LNA & LNNA & STA & TSFA \\
\hline FFA & $\underline{\mathbf{0 . 8 8}}$ & & & & & & & & & \\
MAG & $\underline{\mathbf{0 . 8 3}}$ & 0.78 & & & & & & & & \\
DAG & 0.20 & 0.41 & 0.11 & & & & & & & \\
TAG & -0.55 & -0.64 & -0.69 & 0.01 & & & & & & \\
PAM & $\underline{\mathbf{- 0 . 8 1}}$ & -0.68 & -0.76 & 0.35 & 0.65 & & & & & \\
LNA & 0.03 & -0.24 & -0.04 & $\mathbf{- 0 . 9 6}$ & -0.06 & -0.53 & & & & \\
LNNA & -0.67 & -0.45 & -0.58 & 0.58 & 0.49 & $\underline{\mathbf{0 . 9 4}}$ & -0.74 & & \\
STA & -0.73 & -0.57 & -0.69 & 0.49 & 0.60 & $\mathbf{0 . 9 8}$ & -0.65 & $\mathbf{0 . 9 8}$ & & \\
TSFA & $\underline{\mathbf{- 0 . 8 0}}$ & -0.66 & -0.77 & 0.38 & 0.68 & $\underline{\mathbf{0 . 9 9}}$ & -0.53 & $\underline{\mathbf{0 . 9 4}}$ & $\underline{\mathbf{0 . 9 8}}$ & \\
TUFA & $\underline{\mathbf{- 0 . 9 3}}$ & -0.92 & $\underline{\mathbf{- 0 . 8 5}}$ & -0.37 & 0.60 & $\mathbf{0 . 7 3}$ & 1.14 & $\mathbf{0 . 5 0}$ & $\mathbf{0 . 6 1}$ & 0.68 \\
\hline
\end{tabular}

The sample size was nine $(\mathrm{N}=9(3 \times 3)$ : celery, parsnip and black radish root lipids with three determinations for each one). Only the correlations which were above the absolute value of 0.8 were taken into consideration and there were eight proper and five opposite correlations. The high lipid content indicated high FFA and MAG and low PAM, TSFA and TUFA.

The opposite correlation between MAG and TUFA and between DAG and LNA, indicated that by a higher MAG content in the lipids of celery, parsnip and black radish roots, a lower content of unsaturated fatty acids is indicated, and with a higher content of DAG, the linoleic acid was less abundant. In the lipids of the investigated samples of vegetable roots, the high contribution of palmitic acid was an indicator of a high contribution of linolenic acid, stearic acid and TSFA. A high contribution of linolenic and stearic acid was also the indicator of high TSFA, and a high contribution of linolenic acid indicates a high content of stearic acid.

Based on multiple variables and a cluster analysis, the celery, parsnip and black radish roots were connected to each other. The number of variables was three (celery, parsnip and black radish roots) and the number of cases i.e. lipid parameters was eleven (LC, FFA, MAG, DAG, TAG, PAM, LNA, LNNA, STA, TSFA and TUFA). The obtained linkage distances are presented in the dendrogram in Figure 2.

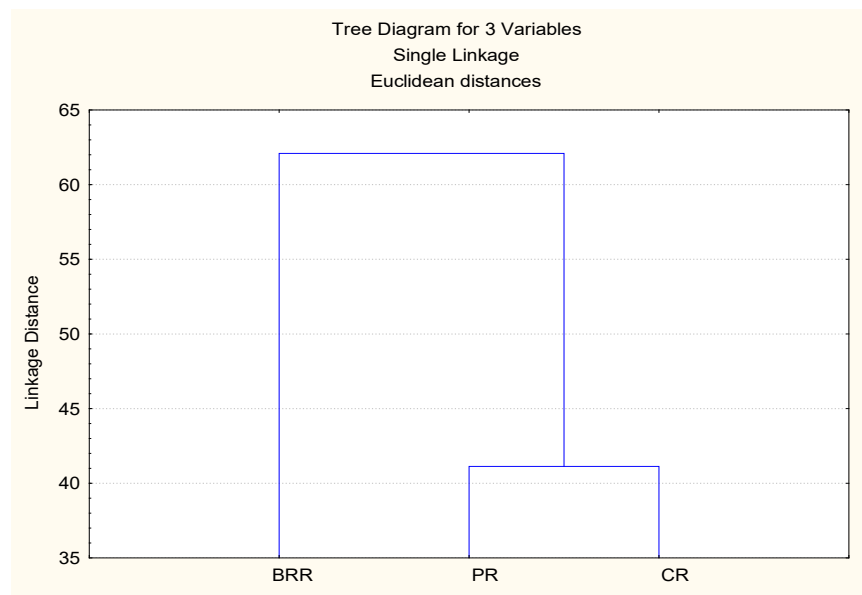

Figure 2. Dendrogram obtained based on eleven parameters of lipids in celery, parsnip and black radish roots 
The celery and parsnip roots were connected to each other at a distance level of 41.1 , and based on the applied lipid parameters were more similar to each other than to the black radish roots, as the linkage distance level of the black radish root and the celery and parsnip roots was 62.3. It shows that for salad and other food products, parsnip may be a better substitute for celery than black radish.

\section{Conclusions}

The results indicate that parsnip roots had the slightly higher lipid content than celery and black radish roots. The lipids in celery, parsnip and black radish roots had higher contents of free fatty acids and triacylglycerols. In the lipids found in celery and parsnip roots it was the linoleic acid, and in the lipids of black radish roots, the linolenic acid was the most abundant acid, so these vegetables are a good source of fatty acids important for human health. Cluster analysis, based on eleven lipid parameters, showed that parsnip may be a better substitute for celery than black radish in food products.

\section{Acknowledgement}

This research was supported by the Ministry of Education, Sciences and Technological Development of the Republic of Serbia under the project Grant No.172047.

\section{References}

[1] H. C. Hung, K. J. Joshipura, R. Jiang, B. F. Hu, D. Hunter, A. S. Smith-Warner, A. G. Colditz, B. Rosner, D. Spiegelman, C. W. Willett, Fruit and vegetable intake and risk of major chronic disease, Journal of the National Cancer Institute, 96(21) (2004) 1577-1584.

[2] T. Anlasik, H. Sies, R. H. Griffiths, P. Mecocci, W. Stahl, C. M. Polidori, Dietary habits are major determinants of the plasma antioxidant status in healthy elderly subjects, British Journal of Nutrition, 94(5) (2005) 639-642.

[3] T. Q. Le, J. W. Elliott, Dose-response relationship of blood pressure and serum holesterol to 3-n-butylphthalide, a component of celery oil, Clinical Research, 39(1991) 750754.

[4] L. J. Slavin, Dietary fiber and body weight, Nutrition, 21(3) (2005) 411-418.

[5] E. Olsson, E. Gustavsson, Root vegetables as healthy convenient food, Acta Horticulturae, 841(841) (2009) 303308.

[6] R. I. Siddiqui, Studies on vegetables: fiber content and chemical composition of ethanol-insoluble and -soluble residues, Journal of Agricultural and Food Chemistry, 37(3) (1989) 647-650.

[7] S. I. Curtis, The noble radish: past, present and future, Trends in Plant Sciences, 8(7) (2003) 305-307.

[8] R. Hänsel, Pflanzliche cholagoga, Deutsche apothekerzeitung, 125 (1985) 1373-1378.

[9] M. Pahlow, Heilpflanze Heute, Grafe und Unzer, Press: $\mathrm{GmbH}$, Munchen, Germany, 1989, p. 279-298.

[10] U. Ritter, Therapie mit Choleretika and Cholekinetika, MedPharm Publications, 7 (1984) 99-104.
[11] F. R. Weiss, Lehrbuch der Phytotherapie, 4. Auflage, Hippokrates-Verlag, Press, Stuttgart, Germany, 1985, p. 161-179.

[12] R. Vargas, M. R. Perez, S. Perez, Antiurolithiatic activity of Raphanus sativus aqueous extract on rats, Journal of Ethnopharmacology, 68(1-3) (1999) 335-338.

[13] L. Bravo, Polyphenols: chemistry, dietary source, metabolism and nutritional significance, Nutrition Reviews, 56(11) (1998) 317-333.

[14] Y. Nakamura, S. Watanabe, N. Miyake, H. Kohno, T. Osawa, Dihydrochalcones: evaluation as novel radical scavenging antioxidants, Journal of Agricultural and Food Chemistry, 51(11) (2003) 3309-3312.

[15] P. Fresco, F. Borges, P. M. Marques, C. Diniz, The anticancer properties of dietary polyphenols and its relation with apoptosis, Current Pharmaceutical Design, 16(1) (2010) 114-134

[16] A. Lugasi, J. Hóvári, V. K. Sági, L. Bíró, The role of antioxidant phytonutritients in the prevention of diseases, Acta Biologica Szegediensis, 47(1-4) (2003) 119-125.

[17] H. Xiuzhen, S. Tao, L. Hongxiang, Dietary polyphenols and their biological significance, International Journal of Molecular Sciences, 8(9) (2007) 950-988.

[18] V. Balázs, in Severe Sepsis and Septic Shock Understanding a Serious Killer, Anti-Inflammatory role of natural polyphenols and their degradation products, Ed by R. Fernandez, InTech, Rijeka, Croatia, 2012, p. 379-410.

[19] A. M. Sitheeque, J. G. Panagoda, J. Yau, M. A. Amarakoon, R. U. Udagama, P. L. Samaranayake, Antifungal activity of black tea polyphenols (catechins and theaflavins) against Candida species, Chemotherapy, 55(3) (2009) 189-196.

[20] C. N. Cook, S. Samman, Flavonoids - Chemistry, metabolism, cardio protective effects and dietary sources, The Journal of Nutritional Biochemistry, 7(2) (1996) 66-76

[21] V. Sonia, C. Alicia, Respiratory activity and phenolic compounds in pre-cut parsnip, Food Chemistry, 100(4) (2007) 1654-1660.

[22] D. Marinova, F. Ribarova, M. Atanassova, Total phenolics and total flavonoids in bulgarian fruits and vegetable, Journal of Chemical Technology and Metallurgy, 40(3) (2005) 255-260.

[23] N. Nikolić, D. Cvetković, Z. Todorović, A Characterization of content, composition and antioxidant capacity of phenolic compounds in celery roots, Italian Journal of Food Science, 23(2) (2011) 214-219.

[24] N. Č. Nikolić, M. M. Lazić, I. T. Karabegović, G. S. Stojanović, Z. B. Todorović, A characterization of content, composition and scavenging capacity of phenolic compounds in parsnip roots of various weight, Natural product communications, 9(6) (2014) 811-814.

[25] N. U. Das, Essential fatty acids: biochemistry, physiology and pathology, Biotechnology Journal, 1(4) (2006) 420439.

[26] P. A. Simopoulos, J. Ordovas, Nutrigenetics and nutrigenomics, World Review of Nutrition and Dietetics, 93 (2004) 1-28.

[27] C. Von Schacky, S. W. Harris, Cardiovascular benefits of omega-3 fatty acids, Cardiovascular Research, 73(2) (2006) 310-315.

[28] N. J. Din, E. D. Newby, D. A. Flapan, Omega-3 fatty acids and cardiovascular disease-fishing for a natural treatment, Clinical Research, 3 (2004) 328-330.

[29] E. Anil, The impact of EPA and DHA on blood lipids and lipoprotein metabolism: influence of apoE genotype, 
Proceedings of the Nutrition Society, 66(1) (2007) 60-68.

[30] A. R. Siddiqui, A. K. Harvey, P. G. Zaloga, Modulation of enzymatic activities by $n-3$ polyunsaturated fatty ac ids to support cardiovascular health, Journal of Nutritional Biochemistry,19(7) (2008) 417-437.

[31] B. H. Sowbhagya, Chemistry, technology, and nutraceutical functions of Celery (Apium graveolens L.): an overview, Critical Reviews in Food Science and Nutrition, 54(3) (2014) 389-398.

[32] M. Holčapek, P. Jandera, J. Fisher, B. Prokeš, Analytical monitoring of biodiesel by high-performance liquid chromatography with various detection methods, Journal of Chromatography A, 858(1) (1999) 13-31.
[33] P. R. M. Gutiérrez, R. L. Perez, Raphanus sativus (Radish): Their Chemistry and Biology, The Scientific World Journal, 4 (2004) 811-837.

[34] S. P. Makarenko, T. A. Konenkina, L. V. Dudareva, Fatty acids of plant vacuolar membrane lipids, Biochemistry (Moscow) Supplement Series A: Membrane and Cell Biology, 1(3) (2007) 228-233.

Izvod

\section{KOMPARATIVNA ANALIZA SASTAVA ACILGLICEROLA I MASNIH KISELINA KORENA CELERA, PAŠKANATA I CRNE ROTKVE}

Jelena S. Mitrović ${ }^{1}$, Nada Č. Nikolić ${ }^{1}$, Ivana T. Karabegović1 ${ }^{1}$ Zoran B. Todorović1, Miodrag M. Lazić1, Gordana S. Stojanović

${ }^{1}$ Tehnološki fakultet, Katedra za prehrambenu tehnologiju i biotehnologiju, Univerzitet u Nišu, Leskovac, Srbija

2Prirodno-matematički fakultet, Departman za hemiju, Univerzitet u Nišu, Niš, Srbija

Celer, paškanat i crna rotkva predstavlja povrće pogodno za pripremu različitih salata. Masne kiseline i acilgliceroli su komponente prisutne u hrani u maloj količini, ali u ljudskoj ishrani neke od njih, kao što su omega-3 i omega-6 masne kiseline, važne su za rast, reprodukciju, dobro zdravlje i sprečavanje kardiovaskularnih bolesti. Zbog toga je identifikacija i upoređivanje sastava lipida iz korena celera, paškanata i crne rotkve od značaja za izbor sirovine, kao i u proceni nutritivnih i zdravstvenih vrednosti prehrambenih proizvoda. $U$ ovom radu je analiziran $i$ upoređen sadržaj lipida, masnih kiselina i acilglicerola korena celera, paškanata i crne rotkve. Rezultati pokazuju da je sadržaj lipida u korenu paškanata veći $(0,077$ $\left.\mathrm{g} \mathrm{kg}^{-1}\right)$ u odnosu na koren celera i crne rotkve $\left(0,036\right.$ i $0,037 \mathrm{~g} \mathrm{~kg}^{-1}$, respektivno). U korenu celera i crne rotkve, u lipidima je utvrđen najveći sadržaj slobodnih masnih kiselina $\left(5,46\right.$ i $\left.4,25 \mathrm{~g} \mathrm{~kg}^{-1}\right)$, dok je u korenu paškanata najveći sadržaj triacilglicerola $\left(4,54 \mathrm{~g} \mathrm{~kg}^{-1}\right)$. Od masnih kiselina u lipidima korena celera i paškanata, najzastupljenija je linolna kiselina (31,03 i 59,22\%, respektivno), dok je u korenu crne rotkve najzastupljenija linolenska kiselina $(55,71 \%)$.
(ORIGINALNI NAUČNI RAD) UDK 582.794.1:577.115:661.188.8

Ključne reči: acilgliceroli, celer, masne kiseline, lipidi, paškanat i crna rotkva 